\title{
Clinical Significance of 18F-Fluorodeoxyglucose Avid Prostate Gland Incidentalomas on Positron Emission Tomography/Computed Tomography
}

\author{
Pozitron Emisyon Tomografisi/Bilgisayarlı Tomografide I8F-Fluorodeoksiglukoz Avid Prostat \\ Bezi Insidentalomalarının Klinik Önemi
}

William Makis', Anthony Ciarallo2

'Cross Cancer Institute, Department of Diagnostic Imaging, Edmonton, Canada

2McGill University Health Centre Glen Site, Department of Nuclear Medicine, Montreal, Canada

\begin{abstract}
Objective: The aim of this study was to evaluate the clinical significance of incidental focal uptake of 18F-fluorodeoxyglucose (18F-FDG) on positron emission tomography/computed tomography (PET/CT) in the prostate glands of cancer patients.

Methods: A retrospective review of 3122 consecutive male patients who underwent 18F-FDG PET/CT studies with an oncologic indication, over the course of four years, was performed. Studies with incidental 18F-FDG uptake in the prostate gland were further analyzed.

Results: Incidental 18F-FDG uptake in the prostate gland was identified in 65/3122 men (2.1\%). Sufficient follow-up data ( $\geq 12$ months) were available in 53 patients, of whom 11 had a biopsy and 42 had clinical and imaging follow-up. Malignancy was histologically diagnosed in 4 out of 53 patients (7.5\%). There was no statistically significant difference in 18 F-FDG uptake values between benign prostate lesions [maximum standardized uptake value $\left(S U V_{\text {max }}\right)$ 7.3] and malignant ones $\left(S U V_{\text {max }}\right.$ $7.2, p=0.95)$. There was a statistically significant difference between the serum prostate specific antigen (PSA) of the benign group ( $n=24, P S A=2.7 \mathrm{ng} / \mathrm{mL}$ ) and the malignant group $(n=4, P S A=9.2 \mathrm{ng} / \mathrm{mL}, p<0.001)$. There was a direct correlation between SUV $_{\text {max }}$ and Gleason score.

Conclusion: 18F-FDG positive prostate incidentalomas were detected in $2.1 \%$ of oncologic PET/CT scans and of these $7.5 \%$ were malignant. SUV $\max$ was not useful for distinguishing between benign and malignant incidental prostate lesions. 18F-FDG avid prostate incidentalomas on PET/CT should prompt a recommendation for obtaining a serum PSA and further investigation if serum PSA is elevated.

Keywords: Prostate incidentaloma, prostate carcinoma, 18F-fluorodeoxyglucose, positron emission tomography/computed tomography, prostate specific antigen
\end{abstract}

Öz

Amaç: Bu çalışmanın amacı kanser hastalarının prostat bezinde pozitron emisyon tomografisi/bilgisayarlı tomografide (PET/ BT) insidental olarak saptanan fokal 18F-fluorodeoksiglukoz (18F-FDG) tutulumunun klinik önemini değerlendirmektir.

Yöntem: Dört yıllık bir dönemde onkolojik nedenlerle 18F-FDG-PET/BT uygulanmış 3122 ardışık erkek hasta retrospektif olarak incelendi. Prostat bezinde insidental 18F-FDG tutulumu saptanan hastalar detaylı olarak değerlendirildi.

Address for Correspondence: William Makis MD, Cross Cancer Institute, Department of Diagnostic Imaging, Edmonton, Canada Phone: 7804328760 E-mail: makisw79@yahoo.com Received: 14.01.2017 Accepted: 16.02.2017

${ }^{\circ}$ Copyright 2017 by Turkish Society of Nuclear Medicine

Molecular Imaging and Radionuclide Therapy published by Galenos Yayınevi. 


\section{Öz}

Bulgular: Prostat bezinde insidental 18F-FDG tutulumu 65/3,122 erkekte $(\% 2,1)$ saptandı. Yeterli takip verisi ( $\geq 12$ ay) olan 53 hasta mevcuttu, bunların 11 'ine biyopsi uygulanmış 42'si klinik ve radyolojik olarak takip edilmişti. Elli üç hastanın dördünde malignite histolojik olarak saptanmıştı $(\% 7,5)$. Benign ve malign prostat lezyonlarında 18 F-FDG tutulum değerleri açısından istatistik olarak anlamlı fark yoktu [maksimum standart uptake değeri (SUV maks) benign: SUV maks 7,3, malign: SUV maks 7,2 , $p=0,95]$. Benign ve malign grup hastalarda serum prostat spesifik antijen (PSA) değerleri arasında istatistiksel olarak anlamlı fark vardı (benign grup $n=24, P S A=2,7 \mathrm{ng} / \mathrm{mL}$, malign grup $n=4, P S A=9,2 \mathrm{ng} / \mathrm{mL}, p<0,001$ ). SUV $\max$ ve Gleason skoru arasında direkt korelasyon mevcuttu.

Sonuç: Onkolojik PET/BT görüntülemelerinin \%2,1'inde 18F-FDG pozitif prostat bezi insidentaloması saptandı ve bunların $\% 7,5^{\prime}$ i malign idi. SUV ${ }_{\text {maks, }}$ benign ve malign insidental prostat lezyonlarını ayırt etmede yararlı değildi. PET/BT'de 18 F-FDG tutulumu olan prostat bezi insidentaloması varlığında serum PSA değerinin bakılması önerilmeli ve eğer PSA yüksek ise ileri tetkik gerekliliği akılda tutulmalıdır.

Anahtar kelimeler: Prostat bezi insidentaloması, prostat kanseri, 18F-fluorodeoksiglukoz, pozitron emisyon tomografisi/ bilgisayarlı tomografi, prostat spesifik antijen

\section{Introduction}

Since positron emission tomography/computed tomography (PET/CT) was first introduced for the staging and follow-up of various malignancies, PET/CT readers have been faced with the challenge of interpreting foci of increased 18F-fluorodeoxyglucose (18F-FDG) uptake in unexpected locations. In addition to malignancy, 18F-FDG uptake has been described in various sites of normal physiologic processes and tracer biodistribution, in benign nodules and masses, and in infectious and inflammatory processes $(1,2,3)$. Increased 18F-FDG activity in locations not typical for metastatic spread in patients known for malignancy may alternatively represent an unrelated benign process or even a second primary malignancy, thus complicating the interpretation of the PET/CT study. The most common locations of potentially malignant incidental 18F-FDG uptake reported in the literature include: breast, gastrointestinal system, the prostate, thyroid, adrenal and parotid glands $(4,5,6,7,8,9,10)$. Locations such as the thyroid, adrenal, and gastrointestinal system have been investigated extensively in the literature, while locations such as the prostate gland continue to confound PET/CT readers.

Several studies have investigated the clinical significance of $18 \mathrm{~F}-\mathrm{FDG}$ positive prostate incidentalomas $(11,12,13,14,15,16,17)$. The aim of this study was to determine the frequency of unexpected focal uptake of $18 \mathrm{~F}-\mathrm{FDG}$ on PET/CT in the prostate glands of cancer patients and to detect the proportion of malignant cases within this group. We examined the possibility of using standardized uptake value $\left(S \cup V_{\max }\right)$ to differentiate benign causes of incidental prostate $18 \mathrm{~F}$-FDG uptake from malignant ones. We also examined if serum prostate specific antigen (PSA) values were different in the benign group as compared to the malignant group.

\section{Materials and Methods}

\section{Study Design and Patient Population}

3122 consecutive male patients who underwent 18F-FDG PET/CT studies with an oncologic indication over the course of 48 months (from January 1, 2006 to December $31,2009)$ were retrospectively reviewed at our institution, a tertiary care academic hospital. The PET/CT reports that made a special reference to focal 18F-FDG uptake in the prostate gland provided the basis for this study.

Sixty-five patients had incidental 18F-FDG uptake in the prostate gland and represented the study group. Patients with a previous prostate malignancy or prostatectomy $(n=3)$ were excluded from the study. Patients with insufficient follow-up data ( $<12$ months) $(n=9)$ were also excluded from this study. The remaining 53 cases constituted the study group for further assessment of clinical significance of incidental $18 \mathrm{~F}-\mathrm{FDG}$ uptake in the prostate gland.

\section{Positron Emission Tomography/Computed Tomography Imaging}

18F-FDG PET/CT studies were performed on a hybrid PET/ CT scanner (Discovery ST, General Electric Medical Systems, Waukesha, WI, USA), which combines a dedicated, fullring PET scanner with a 16-slice CT scanner. Patients were required to fast for at least 6 hours before the time of their appointment, and waited in a quiet dark room the morning of their scan. Blood glucose levels were recorded immediately prior to $18 \mathrm{~F}-\mathrm{FDG}$ administration. If the serum glucose level was greater than $11.1 \mathrm{mmol} / \mathrm{L}(200 \mathrm{mg} / \mathrm{dL})$, the study was rescheduled. A volume of $400 \mathrm{~mL}$ of barium sulfate oral contrast was administered, and $8.14 \mathrm{MBq} / \mathrm{kg}$ of $18 \mathrm{~F}-\mathrm{FDG}$ was injected intravenously up to a maximum dose of $740 \mathrm{MBq}$. Approximately sixty minutes following 18F-FDG injection, CT and PET images were consecutively acquired from the base of the skull to the upper thighs, with 
additional images of the extremities acquired if needed. CT scan settings were: $140 \mathrm{kVp}, 90-110 \mathrm{~mA}$ (depending on the body weight), a rotation time of $0.8 \mathrm{~s}$, a table speed of $17 \mathrm{~mm}$ per gantry rotation, a pitch of $1.75: 1$, and a detector row configuration of $16 \times 0.625 \mathrm{~mm}$. For the PET portion of the study, a 2-D acquisition was performed and images were acquired for 4-5 min per bed position (depending on the body weight) up to 5 to 6 total bed positions (depending on the patient's height). The patient was allowed to breathe normally during the PET and CT acquisitions.

Data obtained from the CT acquisition were used for attenuation correction and fusion with PET images. The PET data were reconstructed iteratively using ordered subset expectation maximization software provided by the manufacturer (21 subsets, 2 iterations). PET attenuation corrected, PET non-attenuation corrected, $\mathrm{CT}$, and PET/CT fusion images of the whole body were displayed in the transaxial, coronal, and sagittal planes and were reviewed on a dedicated workstation (Xeleris 2.0, GE Healthcare, Waukesha, WI, USA). PET data were also displayed in a rotating maximum intensity projection image.

\section{Interpretation and Analysis of Positron Emission Tomography/Computed Tomography Images}

All PET/CT images were interpreted using visualization and semi-quantitative analysis $\left(S \cup V_{\max }\right.$ corrected for body weight) by two experienced nuclear physicians, independently. Any focal 18F-FDG uptake in the prostate gland was noted and each nuclear medicine physician measured the SUV $\max$ corrected for body weight, using a spherical region of interest at the site of the most intense uptake in the prostate gland.

\section{Diagnosis and Follow-up}

Final diagnosis of benign or malignant prostate incidentaloma was based on histologic tissue sampling in 11 of 53 patients. The remaining 42 patients were assessed clinically and/or by serial imaging with magnetic resonance imaging (MRI) or PET/CT. Lesions were considered benign on serial imaging if there was no further evidence of malignancy in the prostate gland or if there was evidence of regression in $S U V_{\max }$ by at least $50 \%$ in the absence of treatment over a period of at least 12 months. Serum PSA values obtained within 6 months of the PET/CT scan were compared in the benign and malignant groups.

\section{Statistical Analysis}

The Mann-Whitney $U$ test was used to determine if there was a significant difference between the mean $S U V_{\max }$ values of the benign and malignant groups. The MannWhitney $U$ (two tailed) test was used to detect a significant difference between the serum PSA values of the benign and malignant groups. A p value less than 0.05 was considered to indicate a statistically significant difference. A correlation between Gleason score and SUV $\max$ was established using the Spearman's rank correlation coefficient.

\section{Results}

The mean age of the study group was 69.3 years (range: 45-87 years). The primary malignant tumors of the cohort and their relative distribution are listed below (Table 1). Incidental focal 18F-FDG uptake in the prostate gland was found in 65 of $3122(2.1 \%)$ men scanned consecutively with PET/CT for an oncologic indication. The mean age of patients with benign prostate lesions was 68.8 years as compared to 74.0 years in patients with prostate malignancy. The distribution of abnormal 18F-FDG prostate uptake in the 53 patients with sufficient follow-up were identified as: peripheral $n=37$ (69.8\%), central $n=7(13.2 \%)$, and multifocal or heterogeneous $n=9(17.0 \%)$ (Table 2).

Histologic tissue sampling was available in 11 of 53 patients, and the remaining 42 patients were assessed clinically and/ or by serial imaging with MRI or PET/CT. The mean clinical follow-up period of these 42 patients was 33 months (range: 12-66 months). Out of 53 patients, 49 (92.5\%)

\section{Table 1. Characteristics of the cohort}

\begin{tabular}{ll}
\hline Demographics & (n=53) \\
\hline Age (years), mean (SD) & $69.3(9.7)$ \\
Age (years), median (IQR) & $69.0(64 ; 76)$ \\
Indication, $\mathbf{n}(\%)$ & \\
Rectal cancer & $17(32.1)$ \\
Lymphoma & $8(15.1)$ \\
Colon cancer & $6(11.3)$ \\
Lung cancer & $6(11.3)$ \\
Malignancy work-up & $5(9.4)$ \\
GIST & $3(5.7)$ \\
Hepatocellular cancer & $2(3.8)$ \\
Bladder cancer & $2(3.8)$ \\
Brain lesion & $1(1.9)$ \\
Cholangiocarcinoma & $1(1.9)$ \\
Gastric cancer & $1(1.9)$ \\
Penile cancer & $1(1.9)$ \\
\hline SD: Standard deviation, IQR: Interquartile range, GIST: Gastrointestinal stromal \\
tumor
\end{tabular}

Table 2. Distribution of prostate ${ }^{18} \mathrm{~F}$-fluorodeoxyglucose uptake

\begin{tabular}{lll}
\hline Site & n (\%) & Cancer \\
\hline Peripheral & $37(69.8)$ & 4 \\
Central & $7(13.2)$ & 0 \\
Heterogeneous & $9(17.0)$ & 0
\end{tabular}


were diagnosed with a benign prostate process and 4 $(7.5 \%)$ were diagnosed with prostate adenocarcinoma. There was no statistically significant difference in terms of the mean $S U V_{\text {max }}$ values between the benign $\left(S U V_{\max } 7.3\right)$ and the malignant group (SUV $\max 7.2)$ (p value 0.95, MannWhitney $U$ test) (Table 3 ). The four malignant prostate incidentalomas were identified in patients with various primary malignancies and all four malignant cases had 18F-FDG uptake in the peripheral zone of the prostate gland (Table 4). The $S U V_{\max }$ range of the four malignant cases was 4.7-9.9, while the $S U V_{\max }$ range of the seven benign biopsied cases was 2.1-22.0, with histology evaluation showing two cases of benign prostatic hyperplasia (BPH) and five cases of benign prostate tissue (Table 5).

Serum PSA values obtained within 6 months of the PET/CT were available in 28 of $53(52.8 \%)$ patients. Of those patients with available serum PSA values, 24 of 28 $(85.7 \%)$ were diagnosed as benign and 4 of $28(14.3 \%)$ were diagnosed as malignant. Mean serum PSA value of patients with a benign prostate process was $2.7 \mathrm{ng} / \mathrm{mL}$ versus $9.2 \mathrm{ng} / \mathrm{mL}$ for patients with a malignant prostate incidentaloma, a statistically significant difference with a $p$ value $<0.001$ by Mann-Whitney $U$ test (Figure 1). The lowest PSA value of the malignant cases was $6.7 \mathrm{ng} / \mathrm{mL}$.

The Gleason scores of the malignant prostate incidentalomas correlated directly with SUV $\max$ (Spearman's rank coefficient, rho=0.996, $p=0.004$ ) (Figure 2).

\section{Discussion}

In our study, $2.1 \%$ of PET/CT scans performed in men with an oncologic indication revealed incidental uptake in the prostate gland, in keeping with previously reported values ranging from $0.6 \%$ to $4.5 \%(11,12,13,14,15,16,17)$. However, the incidence of 18 F-FDG positive prostate incidentalomas that have been confirmed to be malignant varies widely in the literature, from $5.4 \%$ (11) up to $58.0 \%$ (13), making it difficult for the interpreting physician to

Table 3. Benign vs. malignant prostate lesions

\begin{tabular}{|c|c|c|c|}
\hline & Benign $(n=49)$ & Malignant $(n=4)$ & $p$ value \\
\hline Age $(y)$, mean (SD) & $68.8(9.9)$ & $74.0(6.8)$ & 0.32 \\
\hline$S U V_{\text {max }}$, mean (SD) & $7.3(5.3)$ & $7.2(2.5)$ & 0.95 \\
\hline \multirow[t]{2}{*}{$\mathrm{SUV}_{\max }$, range (min.; max.) } & $(2.1 ; 27.0)$ & $(4.7 ; 9.9)$ & - \\
\hline & Benign $(n=24)$ & Malignant $(n=4)$ & \\
\hline PSA, mean (SD) & $2.7(2.0)$ & $9.2(3.1)$ & 0.001 \\
\hline PSA, range (min.; max.) & $0.3-8.9$ & $6.7-13.6$ & - \\
\hline
\end{tabular}

SD: Standard deviation, Min.: Minimum, Max.: Maximum, SUV max $_{\text {: }}$ Maximum standardized uptake value, PSA: Prostate specific antigen

Table 4. Biopsied malignant prostate incidentalomas

\begin{tabular}{lllllll}
\hline Patient & Age & Primary & SUV $_{\text {max }}$ & Site & PSA (ng/mL) & Gleason \\
\hline 1 & 65 & GIST & 9.9 & Peripheral & 7.4 & $10(5+5)$ \\
2 & 81 & Lymphoma & 8.5 & Peripheral & 13.6 & $9(4+5)$ \\
3 & 73 & Cholangioca & 5.5 & Peripheral & 6.7 & $7(3+4)$ \\
4 & 77 & Rectal cancer & 4.7 & Peripheral & 8.9 & $6(3+3)$ \\
\hline
\end{tabular}

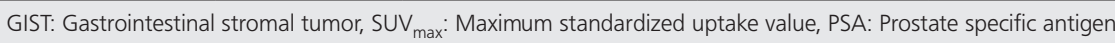

Table 5. Biopsied benign prostate incidentalomas

\begin{tabular}{lllllll}
\hline Patient & Age & Primary & SUV $_{\text {max }}$ & Site & PSA (ng/mL) & Histology \\
\hline 5 & 67 & Rectal cancer & 22.0 & Peripheral & 4.1 & Benign \\
6 & 68 & Lung cancer & 16.2 & Central & 4.2 & Benign \\
7 & 72 & Bladder cancer & 6.4 & Heterogen & 4.1 & BPH \\
8 & 58 & Lymphoma & 4.4 & Peripheral & 2.0 & Benign \\
9 & 64 & Gastric cancer & 3.7 & Heterogen & N/A & Benign \\
10 & 73 & Lymphoma & 3.2 & Peripheral & N/A & Benign \\
11 & 80 & Colon cancer & 2.1 & Peripheral & 8.9 & BPH \\
\hline
\end{tabular}

Note: BPH-benign prostatic hyperplasia, benign-benign prostate tissue, heterogen-heterogeneous, SUV ${ }_{\text {max }}$ : Maximum standardized uptake value, PSA: Prostate specific antigen 

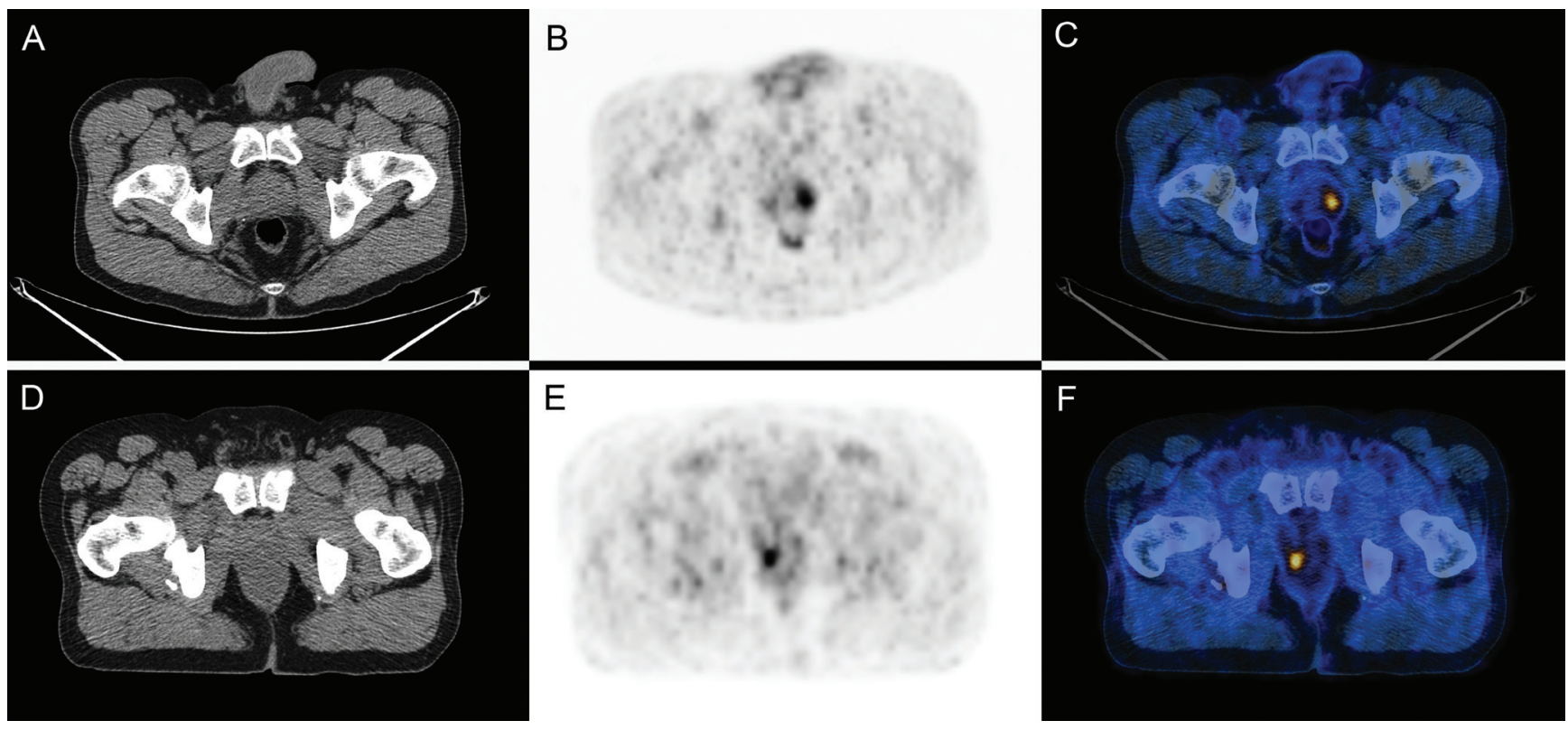

Figure 1. Two histologically confirmed cases of $18 \mathrm{~F}$-fluorodeoxyglucose (18F-FDG) positive prostate incidentaloma, one benign and one malignant, with similar maximum standardized uptake value ( $S U V_{\text {max }}$ ) values. A 58 year old man with previous history of Hodgkin lymphoma (Table 5, patient 8) had a follow-up 18F-FDG positron emission tomography/computed tomography (PET/CT). A serum prostate specific antigen done within 6 months of the $\mathrm{PET} / \mathrm{CT}$ was $2.0 \mathrm{ng} / \mathrm{mL}$ and a biopsy of the prostate did not reveal any malignancy, only benign prostate tissue. A, B, C) Axial PET/CT images show a focus of intense 18 F-FDG uptake in the prostate with $\mathrm{SUV}_{\max } 4.4$, consistent with a false positive. A 77 year old man with a previous history of rectal cancer (Table 4, patient 4) had a follow-up 18F-FDG-PET/CT. A serum prostate specific antigen done within 1 month was $8.9 \mathrm{ng} / \mathrm{mL}$ and biopsy of the prostate showed prostate carcinoma with Gleason score $6(3+3)$. D, E, F) Axial PET/CT images show a focus of 18F-FDG uptake in the prostate with SUV $V_{\max } 4.7$, consistent with a true positive

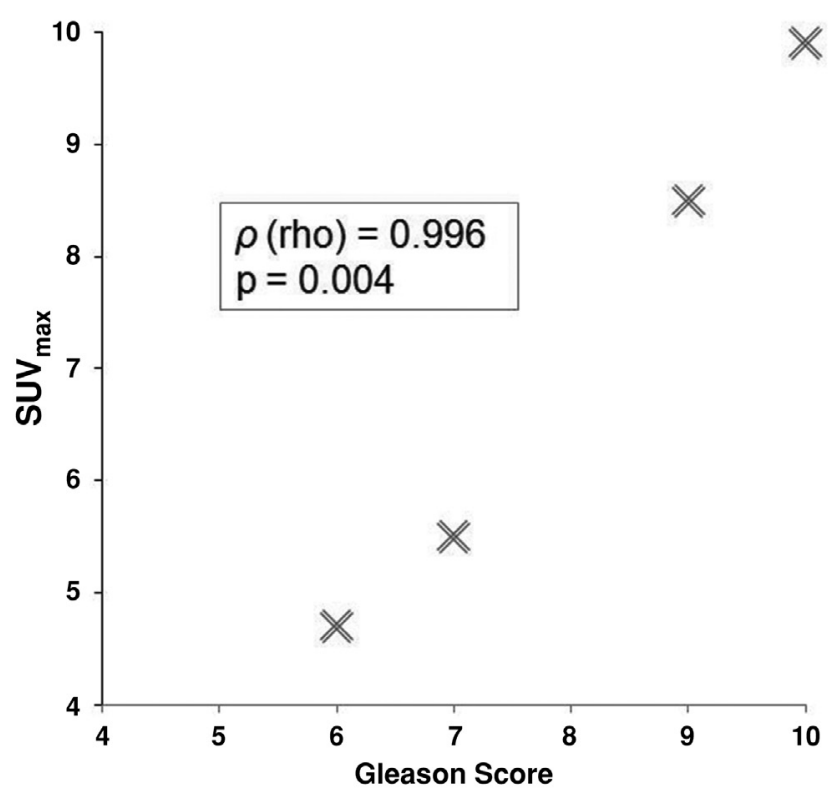

Figure 2. The Gleason scores of the malignant prostate incidentalomas correlated directly with maximum standardized uptake value (Spearman's rank coefficient, rho $=0.996, p=0.004$ )

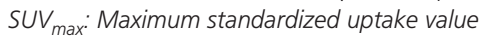

decide what to report or recommend when faced with this uncommon incidental PET/CT finding. In our patient population, $7.5 \%$ (4 of 53 ) of 18F-FDG positive prostate incidentalomas were malignant. There was no particular cancer population which seemed to be at a higher risk of incidental prostate cancer. These findings are similar to those reported by Han et al. (11), who reported prostate malignancy in $5.4 \%$ of 55 incidentalomas. It is important to note that in most prostate incidentaloma papers, a significant number of prostate incidentalomas have not been investigated further and do not have any long term follow-up, likely resulting in an overestimation of reported malignancy rates. Only studies by Han et al. (11) and Seino et al. (15) evaluated most of their prostate incidentalomas [87\% 55/63 by Han et al. (11), 92\% 49/53 by Seino et al. (15)]. Neither of these studies had long term follow-up of their benign prostate incidentalomas. Our mean follow-up period for benign prostate incidentalomas was 33 months. All prostate incidentaloma studies published thus far confirm that quantitative analysis using SUV $V_{\text {max }}$ values alone cannot differentiate benign incidental prostate lesions from malignant ones. Similarly, our data failed to demonstrate a statistically significant difference between mean SUV $V_{\max }$ values for the benign and malignant groups. High SUV $\max$ values have been reported in several benign prostate conditions such as prostatitis (18), BPH (19), as well as other malignant 
prostate conditions $(20,21,22,23)$, such as seminoma (20), sarcomatoid carcinoma (21), and neuroendocrine tumor of the prostate (22). If clinical significance of an 18 F-FDG positive prostate incidentaloma is to be determined, it requires more information than $S U V_{\text {max }}$ alone.

Prostate cancer is often confirmed by histological examination of a sample obtained by needle biopsy. However, this intervention is invasive and unnecessary in the vast majority of patients with 18F-FDG positive prostate incidentalomas. PSA and digital rectal examination are useful non-invasive screening tests routinely used in clinical practice $(24,25,26,27,28,29,30)$. In our population, there was a statistically significant difference between the serum PSA values of benign prostate incidentalomas $(\mathrm{n}=24, \mathrm{PSA}=2.7 \mathrm{ng} / \mathrm{mL})$ and malignant prostate incidentalomas $(n=4, P S A=9.2 \mathrm{ng} /$ $\mathrm{mL}, \mathrm{p}<0.001$ ), which is in keeping with the majority of published studies on 18F-FDG avid prostate incidentalomas $(11,12,13,14,15,16,17)$.

Some investigators have noted a statistically significant association between SUV $\max$ and Gleason score, whereby prostate lesions with higher Gleason scores also had higher SUV $V_{\max }$ values on PET/CT $(31,32)$. Our study found a direct correlation between Gleason score and $S U V_{\text {max }}$ in malignant prostate incidentaloma cases. Even though most 18F-FDG positive prostate incidentalomas are statistically benign, a markedly elevated $S U V_{\max }$ arguably warrants closer follow up in these patients to avoid missing an aggressive malignancy.

There are several limitations to our study. Although the minimum follow-up time was set at 12 months, and the mean period of clinical follow-up of 42 prostate incidentalomas who did not have a biopsy was 33 months, longer follow-up would likely improve the results, especially due to the indolent nature of prostate cancer. Another limitation was that serum PSA values were not obtained in all prostate incidentaloma patients, and the timing of obtained PSA values ranged from the same day of to up to 6 months within the PET/CT. Ideally, serum PSA values should be available in all patients with prostate incidentalomas and performed at the same time as the PET/CT.

Several PSA related indices, such as free-to-total PSA ratio ( $F / T$ ratio), PSA density (PSAD) and PSA transition zone density (PSATZ) could further improve the differentiation of benign 18F-FDG positive prostate incidentalomas from malignant ones. These indices appear to improve cancer detection sensitivity and specificity in patients with low serum PSA levels. The ratio of free-to-total PSA ( $F / T$ ratio) is known to be reduced in cases of prostate cancer. For patients with PSA levels between 4.0 and $10.0 \mathrm{ng} / \mathrm{mL}$, the recommended cut-off value for $F / T$ is $\leq 0.25$. The ideal cut-off for PSAD is $0.15 \mathrm{ng} / \mathrm{mL} / \mathrm{cm}^{3}(26,27,28,29,30)$. These indices may one day play a role in helping determine whether a patient with an 18F-FDG positive prostate incidentaloma is at high risk for harboring a prostate malignancy and should have a biopsy or whether a biopsy is not necessary. Novel PET/CT agents such as gallium-68 (68Ga)- prostate-specific membrane antigen (PSMA) may also become useful in differentiating benign 18F-FDG avid prostate incidentalomas from malignant ones, as several studies have recently reported prostate cancer detection rates by $68 \mathrm{Ga}-\mathrm{PSMA} \mathrm{PET} / \mathrm{CT}$ imaging in the range of 90 $100 \%(33,34,35)$.

\section{Conclusion}

In our patient population, $2.1 \%$ of 18F-FDG PET/CT scans performed in men for an oncologic indication revealed incidental 18F-FDG uptake in the prostate gland. Among those prostate incidentalomas, $7.5 \%$ were malignant. $S U V_{\max }$ alone was unable to differentiate between benign and malignant prostate lesions, however there was a statistically significant difference between the serum PSA of benign and malignant prostate lesions. These findings suggest that obtaining a serum PSA level in a patient with an 18F-FDG positive prostate incidentaloma is a reasonable initial course of action. Patients with significantly elevated serum PSA levels can then be investigated further with biopsy, or followed non-invasively with serial PSAs, clinical examination or follow-up imaging.

\section{Ethics}

Ethics Committee Approval: Retrospective study. Informed Consent: Retrospective study.

Peer-review: Externally peer-reviewed.

\section{Authorship Contributions}

Concept: W.M., Design: W.M., A.C., Data Collection and Processing: A.C., Analysis or Interpretation: W.M., A.C., Literature Search: W.M., A.C., Writing: W.M., A.C.

Conflict of Interest: No conflict of interest was declared by the authors.

Financial Disclosure: The authors declared that this study received no financial support.

\section{References}

1. Cook GJ, Fogelman I, Maisey MN. Normal physiological and benign pathological variants of 18-fluoro-2-deoxyglucose positron emission tomography scanning: potential for error in interpretation. Semin Nucl Med 1996:26:308-314.

2. Bakheet SM, Powe J. Benign causes of 18-FDG uptake on whole body imaging. Semin Nucl Med 1998;28:352-358.

3. Kostakoglu L, Hardoff R, Mirtcheva R, Goldsmith SJ. PET-CT fusion imaging in differentiating physiologic from pathologic FDG uptake. Radiographics 2004;24:1411-1431.

4. Israel O, Yefremov N, Bar-Shalom R, Kagana O, Frenkel A, Keidar Z, Fischer D. PET/CT detection of unexpected gastrointestinal foci of 18F-FDG uptake: incidence, localization patterns, and clinical significance. J Nucl Med 2005;46:758-762.

5. Tatlidil R, Jadvar H, Bading JR, Conti PS. Incidental colonic fluorodeoxyglucose uptake: correlation with colonoscopic and histopathologic findings. Radiology 2002;224:783-787. 
6. Litmanovich D, Gourevich K, Israel O, Gallimidi Z. Unexpected foci of 18F-FDG uptake in the breast detected by PET/CT: incidence and clinical significance. Eur J Nucl Med Mol Imaging 2009;36:15581564.

7. Choi JY, Lee KS, Kim HJ, Shim YM, Kwon OJ, Park K, Baek CH, Chung $J H$, Lee KH, Kim BT. Focal thyroid lesions incidentally identified by integrated 18F-FDG PET/CT: clinical significance and improved characterization. J Nucl Med 2006;47:609-615.

8. Kang BJ, Lee JH, Yoo Ler, Kim SH, Choi JJ, Jeong SH, Yim HW. Clinical significance of incidental finding of focal activity in the breast at 18F-FDG PET/CT. AJR 2011;197:341-347.

9. Metser U, Miller E, Lerman H, Lievshitz G, Avital S, Even-Sapir E. 18F-FDG PET/CT in the evaluation of adrenal masses. J Nucl Med 2006:47:32-37

10. Basu S, Houseni M, Alavi A. Significance of incidental fluorodeoxyglucose uptake in the parotid glands and its impact on patient management. Nucl Med Commun 2008;29:367-373.

11. Han EJ, H O J, Choi WH, Yoo IR, Chung SK. Significance of incidental focal uptake in prostate on 18-fluoro-2-deoxyglucose positron emission tomography CT images. Br J Radiol 2010;83:915-920.

12. Cho SK, Choi JY, Yoo J, Cheon M, Lee JY, Hyun SH, Lee EJ, Lee KH, Kim BT. Incidental focal 18F-FDG uptake in the prostate: clinical significance and differential diagnostic criteria. Nucl Med Mol Imaging 2011;45:192-196.

13. Bhosale P, Balachandran A, Vikram R, Viswanathan C, Macapinlac $H$, Rohren E, Prativadi R. What is the clinical significance of FDG unexpected uptake in the prostate in patients undergoing PET/CT for other malignancies? Int J Mol Imaging 2013;2013:476786.

14. Hwang I, Chong A, Jung SI, Hwang EC, Kim SO, Kang TW, Kwon DD, Park K, Ryu SB. Is further evaluation needed for incidental focal uptake in the prostate in 18-fluoro-2-deoxyglucose positron emission tomography-computed tomography images? Ann Nuc Med 2013;27:140-145.

15. Seino H, Ono S, Miura H, Morohashi S, Wu Y, Tsushima F, Takai Y, Kijima $\mathrm{H}$. Incidental prostate 18F-FDG uptake without calcification indicates the possibility of prostate cancer. Oncol Rep 2014:31:1517-1522.

16. Kang PM, Seo WI, Lee SS, Bae SK, Kwak HS, Min K, Kim W, Kang DI. Incidental abnormal FDG uptake in the prostate on 18-fluoro-2 deoxyglucose positron emission tomography-computed tomography scans. Asian Pac J Cancer Prev 2014;15:8699-8703.

17. Yang Z, Hu S, Cheng J, Xu J, Shi W, Zhu B, Zhang Y, Yao Z, Pan H, Zhang Y. Prevalence and risk of cancer of incidental uptake in prostate identified by fluorine-18 fluorodeoxyglucose positron emission tomography/computed tomography. Clin Imaging 2014;38:470-474.

18. Kao PF, Chou YH, Lai CW. Diffuse FDG uptake in acute prostatitis. Clin Nucl Med 2008;33:308-310.

19. Lawrentschuk N, Davis ID, Bolton DM, Scott AM. Positron emission tomography and molecular imaging of the prostate: an update. BJU Int 2006;97:923-931.

20. Hayasaka K, Koyama M, Fukui I. FDG-PET imaging in a patient with primary seminoma of the prostate. Clin Nucl Med 2011;36:593-594.

21. Goto $T$, Maeshima A, Oyamada $Y$, Kato R. Solitary pulmonary metastasis from prostate sarcomatoid cancer. World J Surg Oncol 2010;19:101.

22. Liu Y. FDG-PET-CT demonstration of metastatic neuroendocrine tumor of the prostate. World J Surg Oncol 2008;6:64.
23. Takahashi N, Inoue T, Lee J, Yamaguchi T, Shizukuishi K. The roles of PET and PET/CT in the diagnosis and management of prostate cancer. Oncology 2007;72:226-233.

24. Loeb S, Gashti SN, Catalona WJ. Exclusion of inflammation in the differential diagnosis of an elevated prostate-specific antigen (PSA). Urol Oncol 2009;27:64-66.

25. Serretta V, Catanese A, Daricello G, Liotta R, Allegro R, Martorana A, Aragona F, Melloni D. PSA reduction (after antibiotics) permits to avoid or postpone prostate biopsy in selected patients. Prostate Cancer Prostatic Dis 2008;11:148-152.

26. Catalona WJ, Partin AW, Slawin KM, Brawer MK, Flanigan RC, Patel A, Richie JP, deKernion JB, Walsh PC, Scardino PT, Lange PH, Subong EN, Parson RE, Gasior GH, Loveland KG, Southwick PC. Use of the percentage of free prostate-specific antigen to enhance differentiation of prostate cancer from benign prostatic disease: a prospective multicenter clinical trial. JAMA 1998;279:1542-1547.

27. Lee R, Localio AR, Armstrong K, Malkowicz SB, Schwartz JS; Free PSA Study Group. A meta-analysis of the performance characteristics of the free prostate-specific antigen test. Urology 2006;67:762-768.

28. Catalona WJ, Southwick PC, Slawin KM, Partin AW, Brawer MK, Flanigan RC, Patel A, Richie JP, Walsh PC, Scardino PT, Lange PH, Gasior GH, Loveland KG, Bray KR. Comparison of percent free PSA, PSA density, and age-specific PSA cutoffs for prostate cancer detection and staging. Urology 2000;56:255-260.

29. Aksoy Y, Oral A, Aksoy H, Demirel A, Akcay F. PSA density and PSA transition zone density in the diagnosis of prostate cancer in PSA gray zone cases. Ann Clin Lab Sci 2003;33:320-323.

30. Horninger $W$, Reissigl A, Klocker $H$, Rogatsch H, Fink K, Strasser $H$, Bartsch G. Improvement of specificity in PSA-based screening by using PSA-transition zone density and percent free PSA in addition to total PSA levels. Prostate 1998:37:133-137.

31. Shiiba $M$, Ishihara $K$, Kimura $G$, Kuwako $T$, Yoshihara $H$, Sato $H$, Kondo Y, Tsuchiya S, Kumita S. Evaluation of primary prostate cancer using 11C-methionine-PET/CT and 18F-FDG PET/CT. Ann Nucl Med 2012;26;138-145.

32. Richter JA, Rodriguez M, Rioja J, Penuelas I, Marti-Climent J, Garrastachu P, Quincoces G, Zudaire J, Garcia-Velloso MJ. Dual tracer 11C-choline and FDG-PET in the diagnosis of biochemical prostate cancer relapse after radical treatment. Mol Imaging Biol 2010:12:210-217.

33. Eiber $M$, Maurer $T$, Souvatzoglou $M$, Beer AJ, Ruffani $A$, Haller $B$, Graner FP, Kübler H, Haberhorn U, Eisenhut M, Wester HJ, Gschwend JE, Schwaiger M. Evaluation of hybrid 68Ga-PSMA ligand PET/CT in 248 patients with biochemical recurrence after radical prostatectomy. J Nucl Med 2015;56:668-674.

34. Koulikov V, Barnes S, Even-Sapir E. 68Ga-PSMA PET-CT in patients with newly diagnosed high-risk prostate cancer. I Nucl Med 2016;57(Suppl 2):1540.

35. Uprimny C, Kroiss AS, Decristoforo C, Fritz J, von Guggenberg $E$, Kendler D, Scarpa L, di Santo G, Roig LG, Maffey-Steffan J, Horninger W, Virgolini IJ. 68Ga-PSMA-11 PET/CT in primary staging of prostate cancer: PSA and Gleason score predict the intensity of tracer accumulation in the primary tumor. Eur J Nucl Med Mol Imaging 2017. 